\title{
DZIAKANIA NA RZECZ ROZWOJU REGIONU W DOKUMENTACH STRATEGICZNYCH UCZELNI W POLSCE W ŚWIETLE ANALIZY TREŚCI. KOMUNIKAT Z BADAŃ
}

\begin{abstract}
Streszczenie
W niniejszym artykule zaprezentowano częściowe wyniki badań dotyczące obecności komponentu działań na rzecz rozwoju regionu w dokumentach strategicznych szkół wyższych w Polsce. Wykorzystując jedną z metod badań niereaktywch - analizę treści, przedstawiono dostępne misje i strategie uczelni pod kątem kierunku oraz obszaru deklarowanych działań na rzecz rozwoju regionalnego.
\end{abstract}

Słowa kluczowe: rozwój regionalny, uczelnie, analiza treści, współpraca

\section{ACTIONS FOR REGIONAL DEVELOPMENT IN STRATEGIC DOCUMENTS OF POLISH UNIVERSITIES: SUMMARY OF RESEARCH FINDINGS}

\section{Summary}

The paper presents partial results of research on the presence of the question of regional development activities in the strategic documents of higher education institutions in Poland. Using a non-reactive method: content analysis, the author explores the available missions and strategies of universities in terms of the direction and the scope of pledged actions for regional development.

Key words: regional development, higher education institutions, content analysis, co-operation

\section{Wstęp}

W Polsce charakter relacji państwo ${ }^{2}$ - uczelnia ${ }^{3}$ można obecnie określić jako ewaluacyjny, co oznacza odejście przez Ustawodawcę od egzekwowania odgórnych zaleceń i przyznanie uczelni, przynajmniej teoretycznie, większej samodzielności i odpowiedzialności za swoją działalność. Bezpośrednia regulacja państwa związana z uczelniami jest zastępowana przez system ewaluacji i instrumentów finansowych. Często w literaturze przedmiotu określa się taki zakres samodzielności uczelni jako autonomie warunkowa [Antonowicz, 2005, s. 165]. Tym samym rośnie znaczenie wpływu określonych inte-

\footnotetext{
1 dr Agnieszka Piotrowska-Piątek - Urząd Statystyczny w Kielcach; e-mail: a.piotrowska-piatek@ stat.gov.pl.

${ }^{2}$ Jest ono rozumiane jako całokształt sfery regulacyjnej.

${ }^{3} \mathrm{~W}$ artykule autorka zamiennie używa pojęć: uczelnia i szkoła wyższa. Rozważania dotyczące różnic terminologicznych między tymi pojęciami Czytelnik znajdzie w: [Drapińska, 2011, s. 29].
} 
resariuszy zewnętrznych: przedsiębiorców, władz publicznych, jednostek otoczenia biznesu, samorządów zawodowych. Zwiększenie oddziaływania poszczególnych podmiotów zewnętrznych następuje w wyniku co najmniej trzech, powiązanych ze sobą czynników: intencji ustawodawcy, by system finansowania uczelni coraz bardziej umożliwiał, ale i wymuszał pozyskiwanie środków od podmiotów zewnętrznych; wyzwań związanych z procesem kształcenia, które niesie ze soba gospodarka typu based knowledge oraz polityki samych uczelni, które we współpracy z otoczeniem upatrują możliwości zwiększania swojej rynkowej konkurencyjności. Nie bez znaczenia jest również zwiększające się poczucie ogólnej współodpowiedzialności społecznej za rozwój danego regionu.

W aktach prawnych, regulujących rynek szkolnictwa wyższego w Polsce, problematyka współpracy uczelni z otoczeniem społeczno-gospodarczym początkowo była traktowana marginalnie, lecz już w 1997 roku Ustawodawca, wprowadzając do systemu szkolnictwa wyższego taki typ uczelni, jakim sa państwowe szkoły wyższe, współpracę taką zdefiniowal jako jedna z powinności szkoły wyższej. Kolejne ustawy Prawo o szkolnictwie ay ¿̇szym z 2005 oraz z 2011 roku rozszerzały obowiązki i możliwości szkół wyższych w zakresie współpracy z otoczeniem, zarówno podmiotowo, jak i przedmiotowo.

Uczelnie, w swych materiałach informacyjno-promocyjnych, często wskazują na takie wyróżniające je cechy, jak współpraca z przedstawicielami: władz samorządowych, regionalnego otoczenia gospodarczego i samorządu zawodowego. Jeśli przyjmie się, że uczelnie w sposób świadomy i odpowiedzialny, projektując i kształtując swoją działalność dydaktyczna, badawczo-rozwojową oraz organizacyjną, zakładaja współpracę z otoczeniem, to powinna ona być wynikiem sprecyzowanych założeń zdefiniowanych na poziomie dokumentów określających przyjętą filozofię działania. Odwołując się do dorobku koncepcji zarządzania strategicznego, za takie dokumenty można uznać misje oraz strategie uczelni. W artykule tym przedstawiono wyniki badań, których podstawową intencją było ustalenie postawy szkół wyższych względem włączania się w procesy rozwoju regionalnego przez diagnozę kierunków, obszarów i podmiotów relacji szkół wyższych z otoczeniem regionalnym. Autorka przeanalizowała zatem dostępne dokumenty strategiczne uczelni pod kątem obecności deklaracji i wizji działania na rzecz rozwoju regionalnego. W niniejszym opracowaniu zaprezentowano częściowe wyniki badań.

\section{Metodyka i organizacja badań}

Język, mówiony i pisany, jest nie tylko istotnym warunkiem działania społecznego w tej mierze, w jakiej polega ono na komunikowaniu znaczeń, ale czynność posługiwania się językiem należy do kategorii zachowań społecznych. Dzięki wyraźnym komunikatom dajemy bowiem wyraz: określonym dążeniom, postawom, ocenie sytuacji, wiedzy oraz przyjmowanym założeniom związanym z otaczającym światem. Owe dążenia, postawy,

\footnotetext{
${ }^{4}$ Przez co rozumie się grupowanie i koordynowanie zasobów: rzeczowych (np. uczelnia jako inwestor), finansowych, ludzkich (np. uczelnia jako pracodawca) $\mathrm{i}$ informacyjnych.
} 
założenia współokreśla system społeczno-kulturowy, w którym funkcjonuje podmiot komunikujący się, i dlatego odzwierciedlają one nie tylko cechy charakterystyczne autorów, lecz również cechy ich społeczności - zinstytucjonalizowane wartości, normy, społecznie zapośredniczone definicje sytuacji. Analiza materiału językowego pozwala więc na wyciaganie wniosków dotyczacych indywidualnych i społecznych zjawisk niejęzykowych [Mayntz, Hubner, 1985, s. 192].

$\mathrm{Z}$ uwagi na powyższe założenia, bazujące na teorii komunikowania społecznego, a także ze względu na zdefiniowany cel badawczy, przeprowadzono analizę dokumentów strategicznych uczelni przy wykorzystaniu analizy treści. Jest ona jedna z metod badań niereaktywnych, a więc takich, w których przedmiotem badania są rzeczy, np. dokumenty. Metoda ta ma zaletę wszystkich metod niereaktywnych, poza tym, umożliwia poprawienie, dostrzeżonych w trakcie badania, błędów za sprawą rekodowania części danych, a nie całości.

Analiza treści to technika badawcza, która w sposób zobiektywizowany i systematyczny ustala i opisuje cechy językowe tekstów po to, aby na jej podstawie wnioskować o niejęzykowych własnościach ludzi i agregatów społecznych (np. organizacji). Obiektywność analizy, rozumiana jako intersubiektywną ważność jej wyników, zapewnia systematyczność, a więc postępowanie badawcze, podporządkowane ustalonym i standaryzowanym regułom. Standaryzację analizy treści zapewnia analiza ilościowa, ale na etapie badań eksploracyjnych i opisowych jest także przydatna analiza jakościowa [Mayntz, Hubner, 1985, s. 193].

Operacjonalizacja zmiennych, zawartych w hipotezach badawczych, w tym przypadku polega na ustaleniu jednostek tekstowych, które będą przedmiotem postępowania analitycznego oraz opracowania tzw. kategorii analitycznych jako podstawy klasyfikacji treści.

Stąd postępowanie badawcze, które opiera się na analizie treści, obejmuje dwa zasadnicze etapy:

- $\quad$ ustalanie cech językowych badanego tekstu (identyfikacja i klasyfikacja treści lub znaczeń określonych konfiguracji językowych w przyjętych jednostkach analizy, najczęściej słów, zwrotów, zdań);

- $\quad$ wnioskowanie oparte na wyodrębnionych cechach jezzykowych o zjawiskach niejęzykowych (na podstawie rodzaju i częstotliwości występowania elementów językowych o sprecyzowanym znaczeniu wnioskuje się o zmiennych niejęzykowych, dotyczących nadawcy tekstu, na przykład: systemu wartości, założonych przez nadawcę cech odbiorcy/odbiorców, przypuszczalnych reakcji odbiorcy na komunikat, cech systemu społeczno-kulturowego, do którego tekst jest kierowany).

Ogniwem, które zmienne, zawarte w hipotezach pozwala powiązać z konfiguracjami językowymi, stanowiącymi wskaźniki tych zmiennych, jest opracowanie kategorii treściowych, mających być podstawą klasyfikacji jednostek tekstowych. Schemat kategorii analitycznych ma zawsze charakter wybiórczy, podyktowany pytaniami badawczymi. Budowa schematu kategorii zaczyna się od ustalenia wymiarów treści, które interesują badacza. W gotowym schemacie każda kategoria sygnuje określoną kategorię znaczeń związana z danym wymiarem treści. Jednostki językowe, występujące w tekście, przyporządkowane 
są do konkretnych kategorii według ich semantycznego podobieństwa. W ten sposób różnorodne artykulacje tych samych treści zostaja zredukowane do klas podobieństwa semantycznego [Mayntz, Hubner, 1985, s. 199-200].

Dążąc do uzyskania jak najbardziej kompletnych i rzetelnych wyników, zdecydowano się na badania pełne. Operat do badań stanowił zatem wykaz uczelni publicznych i niepublicznych o statusie uczelnia działająca, będących pod nadzorem Ministra Nauki i Szkolnictwa Wyższego ${ }^{5}$. Wykaz ustalono na podstawie:

- Rejestru uczelni niepublicznych $i$ zqniazkón uczelni niepublicznych, dostępnego w systemie POL-on';

- Wykazu publicznych uczelni akademickich oraz

- Wykazu państwonych szkót zawodowych ${ }^{8}$.

Jednostkę analizy objęły dokumenty w postaci łącznie misji i strategii lub samej misji ${ }^{9}$, dostępne na stronach WWW uczelni ${ }^{10}$. W nielicznych przypadkach uzyskano dostęp tylko do strategii, a w tekście strategii nie została wyodrębniona i sprecyzowana misja. Jednak należy zaznaczyć, iż określony w trakcie badań odsetek uczelni, które zdefiniowały swoją misję i strategię, może być wyższy, z uwagi na to, że autorka analizowała przekazy publicznie ${ }^{11}$ dostępne na stronie WWW.

Analizę dokumentów przeprowadzono na podstawie kodowania przekazów jawnych, na późniejszych etapach prac poddano je analizie pogłębionej pod kątem występowania przekazów ukrytych. W celu zmniejszenia ryzyka wystąpienia subiektywnej klasyfikacji, w postępowaniu badawczym przyjęto zasadę podwójnego kodowania (metoda sędziów kompetentnych).

Przyjmując eksplicytne znaczenie jednostek językowych, w trakcie prac o charakterze ilościowym kodowanie przekazów miało na celu m.in.:

- stwierdzenie w analizowanym dokumencie obecności komponentu deklarowanego działania na rzecz rozwoju danego regionu lub jego części;

- określenie stopnia nasycenia dokumentów treściami o charakterze regionalnym przez ustalenie częstotliwości używania słów i zwrotów odnoszących się do rozwoju regionalnego ${ }^{12}$;

5 Z uwagi na cel badań, w operacie nie uwzględniono: uczelni, które mają uprawnienia do kształcenia poza granicami Rzeczypospolitej Polskiej, uczelni kościelnych oraz nie będących pod nadzorem Ministra Nauki i Szkolnictwa Wyższego.

${ }^{6}$ Zob.: Dokument elektroniczny, tryb dostępu: [http://polon.nauka.gov.pl/, data wejścia: 30.07.2013].

7 Zob.: Dokument elektroniczny, tryb dostępu: [gov.pl/uczelnie-publiczne/wykaz-uczelni-publicznych-nadzorowanych-przez-ministra-wlasciwego-ds-szkolnictwa-wyzszego-publiczne-uczelnie-akademickie.html, data wejścia: 15.09.2013].

8 Zob.: Dokument elektroniczny, tryb dostępu: [http://www.nauka.gov.pl/uczelniepubliczne/wykazuczelni-publicznych-nadzorowanych-przez-ministra-wlasciwego-ds-szkolnictwa-wyzszego-panstwowewyzsze-szkoly-zawodowe.html, data wejścia: 15.09.2013].

9 Taka sytuacja miała miejsce, jeśli strategia nie była dostępna na stronach internetowych uczelni.

10 Dostęp w dniach 1-30.08.2013.

$11 \mathrm{~W}$ nielicznych przypadkach dostęp do dokumentów wymagał uprawnień.

$12 \mathrm{~W}$ znormalizowanych jednostkach analizy wyodrębniono wersy (pojedyncze linijki tekstu) zawierające słowa i zwroty odnoszące się do rozwoju regionalnego, a następnie określono w każdej jednostce częstotliwość ich występowania w stosunku do ogólnej liczby wersów. 
- $\quad$ wyznaczenie kierunków deklarowanych działań na rzecz rozwoju regionalnego - rozwoju gospodarczego, społecznego, kulturowo-przyrodniczego;

- $\quad$ ustalenie obszaru deklarowanych działań na rzecz rozwoju regionalnego: kształcenia (działalność dydaktyczna i pozadydaktyczna), prac badawczo-naukowych (w tym prac projektowo-wdrożeniowych), działalności organizacyjnej (płaszczyzny: uczelnia jako pracodawca, inwestycje w infrastrukturę techniczna, inwestycje we własnych pracowników);

- $\quad$ sprecyzowanie podmiotów współpracy: regionalne władze publiczne, przedstawiciele biznesu (w tym job-y), inne szkoły wyższe, instytucje edukacyjne, samorząd zawodowy, inne instytucje społeczne (np. ngo'sy).

Przyjęte w analizie wymiary treści oraz kategorie analityczne przedstawia tabela 1. Podstawą do ustalenia schematu kategorii analitycznych dla wymiaru - kierunki deklarowanych działań na rzecz rozwoju regionu - była koncepcja zrównoważonego rozwoju regionalnego. Koncepcja zrównoważonego (trwałego) rozwoju regionu jest wyrazem antropocentrycznego postrzegania zagadnień obejmujących: sferę gospodarcza, społeczną oraz przyrodniczą i ujmuje rozwój regionu w kategoriach zapewnienia mieszkańcom trwałego dobrobytu i ciagłego podnoszenia jakości ich życia. Wyodrębniono zatem takie kategorie analityczne, jak: rozwój gospodarczy, społeczny oraz kulturowo-przyrodniczy. W przypadku drugiego analizowanego wymiaru - obszaru deklarowanych działań własnych - uwzględniono specyfikę działalności uczelni jako organizacji i przyjęto takie kategorie analityczne, jak: działalność w zakresie kształcenia, działalność badawczo-rozwojowa oraz działalność organizacyjna.

TABELA 1.

\section{Schemat kategorii analitycznych przyjętych w badaniu}

\begin{tabular}{|c|c|c|c|c|c|c|}
\hline \multicolumn{7}{|c|}{ Wymiary treści } \\
\hline & \multicolumn{3}{|c|}{$\begin{array}{c}\text { Kierunki deklarowanych działań na } \\
\text { rzecz rozwoju regionu }\end{array}$} & \multicolumn{3}{|c|}{$\begin{array}{c}\text { Obszar deklarowanych działań własnych } \\
\text { na rzecz rozwoju regionalnego }\end{array}$} \\
\hline $\begin{array}{l}\text { Kategorie } \\
\text { analityczne }\end{array}$ & $\begin{array}{l}\text { Rozwój gos- } \\
\text { podarczy }\end{array}$ & $\begin{array}{l}\text { Rozwój } \\
\text { społeczny }\end{array}$ & $\begin{array}{l}\text { Rozwój kul- } \\
\text { turowo- } \\
\text { przyrodniczy }\end{array}$ & $\begin{array}{c}\text { Działalność w } \\
\text { zakresie } \\
\text { kształcenia }\end{array}$ & $\begin{array}{l}\text { Działalność } \\
\text { badawczo- } \\
\text { rozwojowa }\end{array}$ & $\begin{array}{c}\text { Działalność } \\
\text { organizacyjna }\end{array}$ \\
\hline
\end{tabular}

Źródło: opracowanie własne.

Przy stwierdzaniu obecności komponentu działań na rzecz rozwoju regionu oraz kwalifikacji do dalszego postępowania badawczego wzięto pod uwagę występowanie w analizowanych dokumentach:

- określeń przestrzennych w znaczeniu eksplicytnym, takich jak: region, województwo, miasto, regionalny, lokalny, ale również nazw konkretnych regionów Polski (ziem) czy miast lub/oraz

- $\quad$ sformułowań, takich jak: władza samorządowa, otoczenie bliższe (z uwagi na domniemanie lokalności).

Przy kwalifikacji działań na rzecz rozwoju regionalnego oraz ustalaniu związków kategorii w wymiarze kierunków deklarowanych działań uwzględniono następujące jednostki językowe: 
- dla kategorii rozwój gospodarczy: gospodarka, biznes, konkurencyjność, rynek, ekonomia, przedsiębiorstwo, przedsiębiorczość, promocja, innowacyjność, pracodawca/y, inwestycje, ekonomiczny, gospodarczy, biznesowy, konkurencyjny, przedsiębiorczy, innowacyjny, rynkowy;

- dla kategorii rozwój społeczny: społeczeństwo, jakość życia, wspólnota, cywilizacja, dobrobyt, system, społeczny, cywilizacyjny, humanistyczny;

- dla kategorii rozwój kulturowo-przyrodniczy: kultura, przyroda, środowisko naturalne, dziedzictwo, historia, przyrodniczy, kulturowy, historyczny.

Przy kwalifikacji działań na rzecz rozwoju regionalnego oraz ustalaniu związków kategorii w wymiarze obszaru działań własnych posłużono się następującymi jednostkami językowymi:

- dla kategorii działalność dydaktyczna: dydaktyka, nauczanie, działalność dydaktyczna, kształcenie, edukacja, doradztwo, dydaktyczny;

- dla kategorii działalność badawczo-rozwojowa: badania, rozwój, nauka, projekt, wdrożenie, B+R, innowacja, badawczy, rozwojowy, wdrożeniowy, innowacyjny;

- dla kategorii działalność organizacyjna: baza, infrastruktura, pracownik, infrastrukturalny.

Wyodrębnienie podmiotów współpracy regionalnej (tzw. interesariuszy zewnętrznych) poprzedziły studia literaturowe w tym zakresie oraz wstępne zapoznanie się z materiałem badawczym.

\section{Prezentacja wyników badań}

Po opracowaniu operatu do badań na pierwszym etapie prac, analizie poddano strony internetowe badanych uczelni, w celu ustalenia odsetka uczelni publikujących swoje misje i strategie na stronach WWW. Analizę tę przeprowadzono oddzielnie dla każdej z grup uczelni: publicznych uczelni akademickich, państwowych wyższych szkół zawodowych oraz uczelni niepublicznych (tabela 2.).

Jak widać, najwyższym odsetkiem uczelni publikujących swoje dokumenty strategiczne na stronach WWWW charakteryzują się publiczne uczelnie akademickie. Jednak w tym miejscu należy dodać, że w tej grupie uczelni, podgrupa, w której jedynie w jednostkowych przypadkach publikowano misję lub strategię, były akademie wychowania fizycznego. W przypadku państwowych wyższych szkół zawodowych ponad połowa uczelni publikowała swoje misje i strategie na stronach WWW. Najniższy odsetek uczelni publikujących dokumenty strategiczne na stronach WWW wystąpił wśród uczelni niepublicznych.

Kolejnym etapem badawczym było ustalenie obecności komponentu działań na rzecz regionu w dostępnych misjach i strategiach. Tabela 3. prezentuje obecność analizowanego komponentu w misjach lub strategiach uczelni. Stąd w grupie uczelni publicznych obecność komponentu działań na rzecz rozwoju danego regionu stwierdzono w 87,5\% obserwacji. W przypadku państwowych wyższych szkół zawodowych odsetek ten był największy i stanowił ponad 95\%. W odniesieniu do uczelni niepublicznych odsetek ten był najniższy i wynosił niewiele ponad 56\%. Jednak należy pamiętać o zróżnicowaniu 
grup uczelni w zakresie publikowania swoich dokumentów strategicznych na stronach WWW (tabela 2.). Jeśli to weźmie się pod uwagę, to grupą uczelni, w której najczęściej obserwowano odwołania regionalne, były publiczne uczelnie akademickie (71\%), a najrzadziej uczelnie niepubliczne $(28 \%)$.

TABELA 2.

Odsetek uczelni publikujących swoje dokumenty strategiczne na stronach WWW (N-386)

\begin{tabular}{|c|c|c|}
\hline \multicolumn{3}{|c|}{ Publiczne uczelnie akademickie } \\
\hline $\begin{array}{c}\text { Liczba uczelni ogółem w tej } \\
\text { kategorii }\end{array}$ & $\begin{array}{c}\text { Odsetek uczelni publikujących } \\
\text { misję (\%) }\end{array}$ & $\begin{array}{c}\text { Odsetek uczelni publikujących } \\
\text { strategię (\%) }\end{array}$ \\
\hline 59 & 79,6 & 59,3 \\
\hline \multicolumn{3}{|c|}{ Państwowe wyższe szkoły zawodowe } \\
\hline $\begin{array}{c}\text { Liczba uczelni } \\
\text { ogółem w tej kategorii }\end{array}$ & $\begin{array}{c}\text { Odsetek uczelni publikujących } \\
\text { misję (\%) }\end{array}$ & $\begin{array}{c}\text { Odsetek uczelni publikujących } \\
\text { strategię (\%) }\end{array}$ \\
\hline 36 & 55,5 & 52,7 \\
\hline \multicolumn{3}{|c|}{ Uczelnie niepubliczne ${ }^{13}$} \\
\hline $\begin{array}{c}\text { Liczba uczelni ogółem w tej } \\
\text { kategorii }\end{array}$ & $\begin{array}{c}\text { Odsetek uczelni publikujących } \\
\text { misję (\%) }\end{array}$ & $\begin{array}{c}\text { Odsetek uczelni publikujących } \\
\text { strategię } \\
(\%)\end{array}$ \\
\hline 291 & 48,8 & 10,9 \\
\hline
\end{tabular}

Źródło: opracowanie na podstawie badań własnych.

TABELA 3.

Obecność komponentu działań na rzecz rozwoju regionalnego w dokumentach strategicznych uczelni, dostępnych na stronach WWW (N-214)

\begin{tabular}{|l|c|}
\hline \multicolumn{1}{|c|}{ Typ uczelni } & $\begin{array}{c}\text { Udział wśród uczelni publikujących do- } \\
\text { kumenty strategiczne (w \%) }\end{array}$ \\
\hline Publiczne uczelnie akademickie & 87,5 \\
Państwowe wyższe szkoły zawodowe & 95,7 \\
Uczelnie niepubliczne & 56,6 \\
\hline
\end{tabular}

Źródło: opracowanie na podstawie badań własnych.

Dostępne dokumenty strategiczne uczelni badano również pod kątem nasycenia treściami o charakterze regionalnym. W tym celu, jak wspomniano wcześniej, pojedyncze jednostki analizy rozpatrywano pod kątem częstości występowania określonych jednostek językowych w stosunku do sumarycznej liczby jednostek językowych, składających się na dany dokument.

Na skali procentowej rozważane nasycenie wahało się od $0,23 \%$ do $30,77 \%$, przy średniej wynoszącej 7,4\%, medianie 5,2\% i dominancie 5,9\% (z pominięciem szkół, których misje i strategie nie zawierały takich treści, $\mathrm{N}=69$, tzw. brak zaangażowania). Przyjęto następujące warianty badanej cechy:

${ }^{13} \mathrm{~W}$ okresie, w którym prowadzono badania, w przypadku 11 uczelni strona WWW nie działała lub pojawiał się komunikat „strona w budowie” czy też uczelnia nie posiadała strony WWW. 
- bardzo duży stopień zaangażowania;

- duży stopień zaangażowania;

- umiarkowany stopień zaangażowania;

- niewielki stopień zaangażowania;

- brak zaangażowania.

W rozkładzie ogółem, licząc od kwartyli procentowego nasycenia dokumentów treściami regionalnymi, stwierdzono, że:

- 69 szkół wyższych wyróżnia „brak zaangażowania” (32,2\%);

- nasycenie treści poniżej pierwszego kwartyla udziału procentowego treści w dokumentach ogółem (3,03\%, tzw. niewielki stopień zaangażowania) odnosi się do 35 szkół (16,4\%);

- nasycenie treści do mediany udziału procentowego treści w dokumentach ogółem $(5,19 \%$, tzw. umiarkowany stopień zaangażowania) odnosi się do 38 szkół $(17,8 \%)$;

- nasycenie treści do kwartyla trzeciego udziału procentowego treści w dokumentach ogółem (10,44\%, tzw. duży stopień zaangażowania) odnosi się do 36 szkół (16,8\%);

- $\quad$ nasycenie treści powyżej kwartyla trzeciego udziału procentowego treści w dokumentach ogółem (10,44\%, tzw. bardzo duży stopień zaangażowania) odnosi się do 36 szkół (16,8\%).

Podział ten, jak stwierdzono, ma istotny związek z typem szkoły. Dane przedstawia rysunek 1.

Poza tym, należy dodać, że w świetle jednoczynnikowej analizy wariancji i testu Scheffego procentowe nasycenie dokumentów treściami regionalnymi było jednorodne (podobne) w grupach szkół zaliczonych do kategorii braku lub niewielkiego stopnia zaangażowania (średnie nasycenie wynosiło odpowiednio: 0,00\% i 1,63\%), zaś pozostałe grupy szkół wyraźnie różnicował przeciętny poziom nasycenia treściami regionalnymi (w grupie umiarkowanego nasycenia przeciętnie 4,04\%, w grupie dużego nasycenia $7,38 \%$, w grupie bardzo dużego nasycenia - 16,65\%).

Jak wyjaśniono wcześniej, w prowadzonych obserwacjach ustalono dwa wymiary treści: kierunek oraz obszar deklarowanych działań. Tabela 4. przedstawia obecność w badanych dokumentach strategicznych, przyjętych w analizie, kategorii analitycznych dla wymiaru kierunek deklarowanych działań. Jak widać, państwowe szkoły wyższe były ta grupa uczelni, w której deklaracje działań na rzecz rozwoju gospodarczego, społecznego oraz przyrodniczo-kulturowego danego regionu były najczęstsze. Na drugim biegunie znalazły się uczelnie niepubliczne. W tym przypadku, w każdej kategorii analitycznej, odnotowano stosunkowo najniższy udział danych treści językowych, wskazujących na deklarację działań na rzecz rozwoju regionalnego. W odniesieniu do państwowych szkół wyższych w dokumentach strategicznych najczęściej deklarowano działania na rzecz rozwoju gospodarczego i społecznego. W każdej grupie uczelni, najrzadziej w dokumentach strategicznych, stwierdzano obecność motywu przyrodniczo-kulturowego. 
RYSUNEK 1.

\section{Rozkłady współzależności typu szkoły z nasyceniem dokumentów strate- gicznych uczelni treściami regionalnymi (\%)}
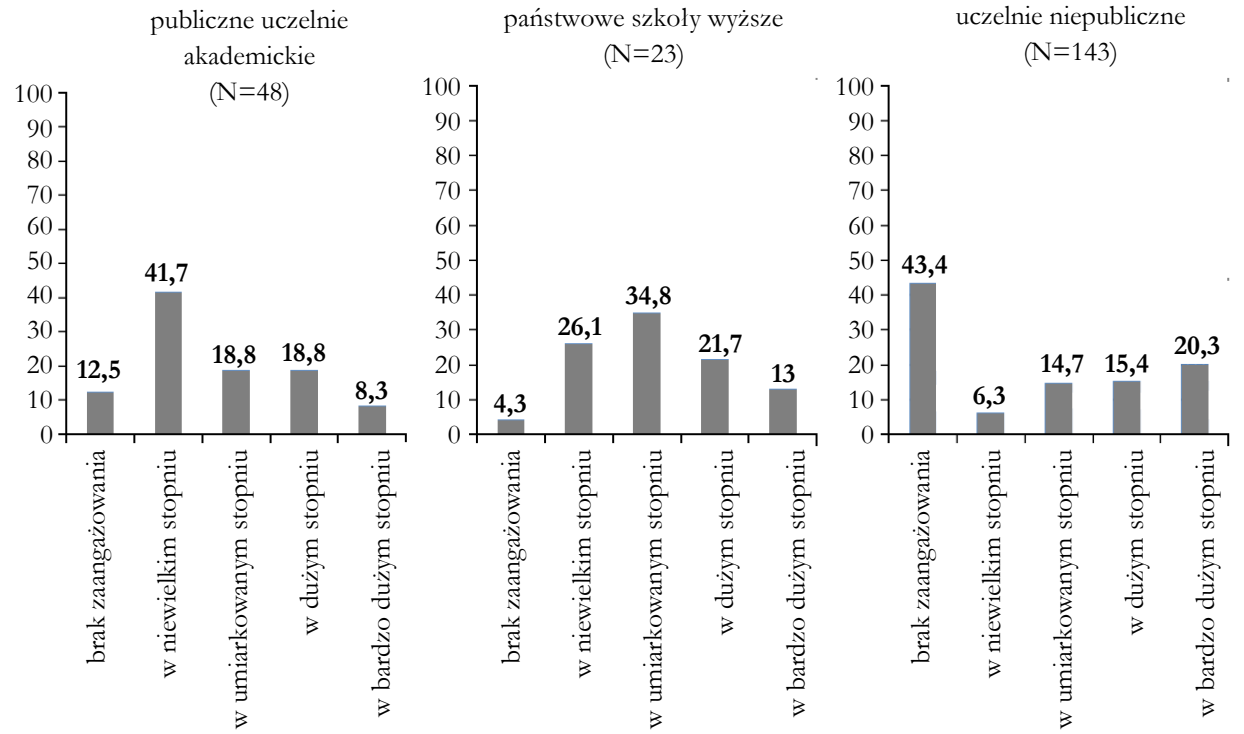

Źródło: opracowanie na podstawie badań własnych.

TABELA 4.

Obecność przyjętych kategorii analitycznych dla wymiaru kierunek deklarowanych działań $w$ dokumentach strategicznych uczelni (w\%), (N-145)

\begin{tabular}{|c|c|c|c|}
\hline \multirow{3}{*}{ Kategoria analityczna } & Rozwój gospodarczy & Rozwój społeczny & $\begin{array}{c}\text { Rozwój przyrodniczo- } \\
\text { kulturowy }\end{array}$ \\
\cline { 2 - 4 } & 66,7 & 81,0 & 54,8 \\
\hline \multicolumn{3}{|c|}{ Państwowe wyższe szkoły zawodowe (N=22) } \\
\hline Kategoria analityczna & Rozwój gospodarczy & Rozwój społeczny & $\begin{array}{c}\text { Rozwój przyrodniczo- } \\
\text { kulturowy }\end{array}$ \\
\cline { 2 - 4 } & 86,4 & 86,4 & 63,6 \\
\hline Kategoria analityczna & Rozwój gospodarczy & Rozwój społeczny & $\begin{array}{c}\text { Rozwój przyrodniczo- } \\
\text { kulturowy }\end{array}$ \\
\cline { 2 - 4 } & 53,1 & 42,0 & 22,2 \\
\hline
\end{tabular}

Źródło: opracowanie na podstawie badań własnych.

Drugim, przyjętym w postępowaniu badawczym, wymiarem treści był obszar deklarowanych działań. Uwzględniając specyfikę funkcjonowania uczelni, wyodrębniono trzy kategorie analityczne: kształcenie, działalność badawczo-naukową oraz działalność organizacyjna. Obszarem, w którym uczelnie najczęściej deklarowały działania na rzecz rozwoju regionalnego, było kształcenie. W przypadku państwowych szkół wyższych dekla- 
racje w tym obszarze zauważono we wszystkich badanych na tym etapie jednostkach. Z kolei, w obszarze działalności badawczo-naukowej najczęściej takie deklaracje były notowane w grupie publicznych uczelni akademickich. Najniższe odsetki w każdej kategorii analitycznej stwierdzono w grupie uczelni niepublicznych (tabela 5.).

TABELA 5.

Obecność przyjętych kategorii analitycznych dla wymiaru obszar deklarowanych działań w dokumentach strategicznych uczelni $(w \%),(\mathrm{N}-145)$

\begin{tabular}{|c|c|c|c|}
\hline \multirow{4}{*}{ Kategoria analityczna } & Kształcenie & $\begin{array}{c}\text { Działalność badaw- } \\
\text { czo-naukowa }\end{array}$ & $\begin{array}{c}\text { Działalność organiza- } \\
\text { cyjna }\end{array}$ \\
\cline { 2 - 4 } & 73,8 & 83,3 & 31,0 \\
\hline \multicolumn{4}{|c|}{ Państwowe wyższe szkoły zawodowe (N=22) } \\
\hline Kategoria analityczna & Kształcenie & $\begin{array}{c}\text { Działalność badaw- } \\
\text { czo-naukowa }\end{array}$ & $\begin{array}{c}\text { Działalność organiza- } \\
\text { cyjna }\end{array}$ \\
\hline & 100,0 & 72,7 & 77,3 \\
\hline Kategoria analityczna & Uształcenie numie & $\begin{array}{c}\text { Działalność badaw- } \\
\text { czo-naukowa }\end{array}$ & $\begin{array}{c}\text { Działalność organiza- } \\
\text { cyjna }\end{array}$ \\
\cline { 2 - 4 } & 63,0 & 27,2 & 9,9 \\
\hline
\end{tabular}

Źródło: opracowanie na podstawie badań własnych.

Jednym z celów badawczych było również ustalenie kluczowych podmiotów w zakresie potencjalnej współpracy, do których uczelnie odwoływały się w swoich dokumentach strategicznych. Wyodrębniono sześć, zasadniczych grup interesariuszy zewnętrznych, tj.:

- $\quad$ władze publiczne (władze samorządowe, władze administracyjne);

- $\quad$ przedstawiciele gospodarki (przedsiębiorcy, jednostki otoczenia biznesu);

- samorząd zawodowy;

- $\quad$ inne szkoły wyższe;

- $\quad$ instytucje społeczne (inne niż władza publiczna, np. stowarzyszenia, inne niż samorząd zawodowy, instytucje kultury);

- $\quad$ instytucje edukacyjne (inne niż szkoły wyższe, np. szkoły ponadgimnazjalne, towarzystwa edukacyjno-naukowe).

Jak pokazuje tabela 6., uczelnie w swoich misjach i strategiach najczęściej deklaracje współpracy kierowały pod adresem przedstawicieli sfery gospodarczej oraz władz publicznych. Te dwa typy podmiotów wydają być się głównymi partnerami do współdziałania na rzecz rozwoju regionalnego, przy czym najczęściej taką współpracę deklarowały państwowe wyższe szkoły zawodowe i uczelnie publiczne. Generalnie, w dokumentach tych dwóch typów uczelni zdecydowanie częściej obserwowano odwoływanie się do zdefiniowanych typów partnerów regionalnych. Należy zauważyć, że najczęściej deklarację współpracy z innymi szkołami wyższymi można było znaleźć w dokumentach strategicznych państwowych wyższych szkół zawodowych. Prawdopodobnie jest to spowodowane specyfiką tej grupy uczelni, podyktowaną czynnikami formalnoorganizacyjnymi. 
TABELA 6.

Obecność interesariuszy zewnętrznych w dokumentach strategicznych uczelni (w \%), (N-145)

\begin{tabular}{|c|c|c|c|c|c|}
\hline \multicolumn{6}{|c|}{ Publiczne uczelnie akademickie $(\mathrm{N}=42)$} \\
\hline $\begin{array}{c}\text { Wradze } \\
\text { publiczne }\end{array}$ & $\begin{array}{c}\text { Przedstawiciele } \\
\text { gospodarki }\end{array}$ & $\begin{array}{c}\text { Samorząd } \\
\text { zawodowy }\end{array}$ & $\begin{array}{l}\text { Szkoły } \\
\text { wyższe }\end{array}$ & $\begin{array}{l}\text { Instytucje } \\
\text { społeczne }\end{array}$ & $\begin{array}{l}\text { Instytucje } \\
\text { edukacyjne }\end{array}$ \\
\hline 42,9 & 57,1 & 40,5 & 42,9 & 38,1 & 40,5 \\
\hline \multicolumn{6}{|c|}{ Państwowe wyższe szkoły zawodowe $(\mathrm{N}=22)$} \\
\hline $\begin{array}{l}\text { Władze } \\
\text { publiczne }\end{array}$ & $\begin{array}{c}\text { Przedstawiciele } \\
\text { gospodarki }\end{array}$ & $\begin{array}{l}\text { Samorzad } \\
\text { zawodowy }\end{array}$ & $\begin{array}{l}\text { Szkoły } \\
\text { wyższe }\end{array}$ & $\begin{array}{l}\text { Instytucje } \\
\text { społeczne }\end{array}$ & $\begin{array}{l}\text { Instytucje } \\
\text { edukacyjne }\end{array}$ \\
\hline 68,2 & 72,7 & 40,9 & 72,7 & 54,5 & 40,9 \\
\hline \multicolumn{6}{|c|}{ Uczelnie niepubliczne $(\mathrm{N}=81)$} \\
\hline $\begin{array}{l}\text { Władze } \\
\text { publiczne }\end{array}$ & $\begin{array}{c}\text { Przedstawiciele } \\
\text { gospodarki }\end{array}$ & $\begin{array}{l}\text { Samorząd } \\
\text { zawodowy }\end{array}$ & $\begin{array}{l}\text { Szkoły } \\
\text { wyższe }\end{array}$ & $\begin{array}{l}\text { Instytucje } \\
\text { społeczne }\end{array}$ & $\begin{array}{l}\text { Instytucje } \\
\text { edukacyjne }\end{array}$ \\
\hline 21,0 & 25,9 & 12,3 & 11,1 & 8,6 & 12,3 \\
\hline
\end{tabular}

Źródło: opracowanie na podstawie badań własnych.

W świetle powyższych wyników badań wydaje się, że uczelnie w Polsce dostrzegaja znaczenie budowania oferty programowej oraz działalności badawczo-naukowej dzięki współpracy z różnymi kategoriami interesariuszy zewnętrznych. Wniosek taki jest zasadny szczególnie w przypadku uczelni publicznych i państwowych wyższych szkół zawodowych.

\section{Podsumowanie}

Obecnie, bardzo często w literaturze przedmiotu podkreśla się, że rozwój w warunkach gospodarki opartej na wiedzy wymaga zacieśnienia współpracy między sferami edukacji, nauki a biznesu. Innowacyjność i konkurencyjność współczesnych gospodarek coraz bardziej zależy od umiejętności organizowania relacji partnerskich między uczelniami a przedsiębiorstwami. Rozwój tego typu powiązań jest także istotny z racji budowania konkurencyjności poszczególnych firm, jak również uczelni, które rywalizują na rynku usług edukacyjnych [Bryła, Jurczyk, Domański, 2013, s. 10].

W niniejszym artykule opisano częściowe wyniki badań dotyczących obecności komponentu działań na rzecz rozwoju regionu w dokumentach strategicznych szkół wyższych w Polsce. Badanie to jest częścią szerszego, własnego projektu badawczego autorki związanego z problematyką roli uczelni wyższych w rozwoju społeczno-gospodarczym regionu. Wykorzystując jedną z metod badań niereaktywch - analizę treści, przedstawiono dostępne misje i strategie uczelni.

W świetle powyższych badań wydaje się, że uczelnie w Polsce, jako element regionu, ujmowanego w kategoriach określonej rzeczywistości społecznej, wyodrębnionej przestrzennie, świadome są roli, jaką odgrywają w procesach jego rozwoju: społecznego, gospodarczego i kulturowo-przyrodniczego. Na tle przeprowadzonych badań świadomość ta, a co za tym idzie, deklaracje konkretnych działań są zróżnicowane z uwagi na typ uczelni.

Świadczą o tym nie tylko zaprezentowane wyniki badań ilościowych, ale również pogłębione badania jakościowe. Przykładowo, sformułowania, takie jak: uč̨elnia jest krea- 
torem rozwoju regionu; uniwersytet ma obowiqzek wypowiadania sie w sprawach szczególnie ważyych dla regionu; angażijemy sie w sprawy ważne dla gospodarki i społeczeństwa, poczynajac od macierzystego regionu, pokazuja, że uczelnie dostrzegaja, jak są istotnym podmiotem w procesach rozwoju regionalnego.

\section{Literatura}

Antonowicz D. 2005 Uniwersytet prayszz̨ości. Wyzzwania i modele polityki, Instytut Spraw Publicznych, Warszawa.

Bryła P., Jurczyk T., Domański T. 2013 Klasyfikacja barier podejmowania wspólpracy z otoczeniem gospodarczym przez. uczelnie wy ̌sze, „Marketing i Rynek”, nr 5.

Drapińska A. 2011 Zarzqdzanie relacjami na rynku edukacyjnych ustug my:ssych, PWN, Warszawa.

Mayntz R., Hubner K. 1985 Wprowadzenie do metod socjologii empirycznej, PWN, Warszawa.

Ustawa z dnia 12 września 1990 roku o szlkolnictwie wy:ssym (Dz. U., 1990, $\mathrm{Nr}$ 65, poz. 385).

Ustawa z. dnia 26 czerwca 1997 roku o myissych szkołach zawodonych (Dz. U. z 1997 roku, $\mathrm{Nr}$ 96, poz. 590).

Ustawa Prawo o szkolnictwie my šşym z 27 lipca 2005 roku (Dz. U. z 2005 roku, Nr 164, poz. 1365; z 2006 roku, $\mathrm{Nr} 46$, poz. 328).

Ustawa Prawo o szkolnictwie mysssym z 18 marca 2011 roku (Dz. U., Nr 164, poz. 1365, z późn. zm.). 